\title{
Pitfalls of vaccinations with WT1-, Proteinase3- and MUC1- derived peptides in combination with MontanideISA51 and CpG7909
}

\author{
Jürgen Kuball · Karin de Boer · Eva Wagner • Mohammed Wattad • Edite Antunes • \\ Risini D. Weeratna · Alain P. Vicari · Carina Lotz $\cdot$ Suzanne van Dorp · Samantha Hol • \\ Philip D. Greenberg • Wolfgang Heit $\cdot$ Heather L. Davis $\cdot$ Matthias Theobald
}

Received: 9 August 2010/Accepted: 6 October 2010/Published online: 21 October 2010

(C) The Author(s) 2010. This article is published with open access at Springerlink.com

\begin{abstract}
T}$ cells with specificity for antigens derived from Wilms Tumor gene (WT1), Proteinase3 (Pr3), and mucin1 (MUC1) have been demonstrated to lyse acute myeloid leukemia (AML) blasts and multiple-myeloma (MM) cells, and strategies to enhance or induce such tumor-specific $\mathrm{T}$ cells by vaccination are currently being explored in multiple clinical trials. To test safety and immunogenicity of a vaccine composed of WT1-, Pr3-, and MUC1-derived Class I-restricted peptides and the pan HLA-DR T helper cell epitope (PADRE) or MUC1-helper epitopes in combination with CpG7909 and MontanideISA51, four patients with AML and five with MM were repetitively vaccinated. No clinical responses were observed. Neither pre-existing nor naive WT1-/Pr3-/ MUC1-specific $\mathrm{CD} 8^{+} \mathrm{T}$ cells expanded in vivo by vaccination. In contrast, a significant decline in vaccine-specific
\end{abstract}

Electronic supplementary material The online version of this article (doi:10.1007/s00262-010-0929-7) contains supplementary material, which is available to authorized users.

J. Kuball $(\bowtie) \cdot$ K. de Boer $\cdot$ C. Lotz $\cdot$ S. van Dorp $\cdot$ S. Hol Department of Hematology, University Medical Center Utrecht, Huispostnr.: KC02.085.2, Lundlaan 6, 3584 EA Utrecht,

The Netherlands

e-mail: j.h.e.kuball@umcutrecht.nl

J. Kuball · K. de Boer - C. Lotz · S. van Dorp · S. Hol Department of Immunology, University Medical Center Utrecht, Huispostnr.: KC02.085.2, Lundlaan 6, 3584 EA Utrecht, The Netherlands

R. D. Weeratna · A. P. Vicari - H. L. Davis

Pfizer Vaccine Research, Ottawa, ON, Canada

Present Address:

A. P. Vicari

Merck Serono S.A., Geneva, Switzerland
$\mathrm{CD}^{+} \mathrm{T}$ cells was observed. An increase in PADRE-specific $\mathrm{CD} 4^{+} \mathrm{T}$ helper cells was observed after vaccination but these appeared unable to produce IL2, and $\mathrm{CD}^{+}{ }^{+} \mathrm{T}$ cells with a regulatory phenotype increased. Taken into considerations that multiple clinical trials with identical antigens but different adjuvants induced vaccine-specific $\mathrm{T}$ cell responses, our data caution that a vaccination with leukemia-associated antigens can be detrimental when combined with MontanideISA51 and CpG7909. Reflecting the time-consuming efforts of clinical trials and the fact that $1 / 3$ of ongoing peptide vaccination trails use $\mathrm{CpG}$ and/or Montanide, our data need to be taken into consideration.

Keywords Vaccination $\cdot \mathrm{AML} \cdot \mathrm{MM} \cdot \mathrm{T}$ cell $\cdot \mathrm{CpG}$. WT1

E. Wagner - E. Antunes - M. Theobald

Department of Hematology, Johannes Gutenberg-University, Mainz, Germany

M. Wattad - W. Heit

Department of Hematology, Kliniken Essen Süd, Essen,

Germany

P. D. Greenberg

Program in Immunology, Fred Hutchinson Cancer Research

Center, Seattle, WA 98109, USA

P. D. Greenberg

Department of Immunology, University of Washington School

of Medicine, Seattle, WA 98195, USA 


\section{Introduction}

Several lines of investigation have provided conclusive evidence that epitopes derived from Wilms Tumor1 (WT1) and Proteinase $3(\operatorname{Pr} 3)$ are presented in the context of major histocompatibility complex (MHC) class I epitopes on solid cancer cells and/or leukemic blasts, and are potentially immunogenic. Molldrem et al. [1] identified $\operatorname{Pr} 3_{169-177}$, a nine-amino acid self-peptide derived from $\operatorname{Pr} 3$ that binds HLA-A*0201 as a leukemia-associated $\mathrm{CD}^{+} \mathrm{T}$

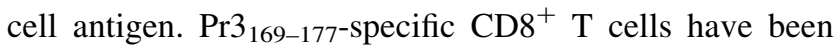
isolated from healthy donors and from patients with chronic myeloid leukemia (CML), shown to kill CML and acute myeloid leukemia (AML) cells but not normal hematopoietic progenitors expressing low levels of these antigens, and to effectively inhibit the outgrowth of a panel of CML progenitors in proportion to the level of $\operatorname{Pr} 3$ overexpression [2]. WT1-derived HLA-A*0201-presented epitopes, including the HLA-A*0201-presented epitope WT1 $1_{126-134}$, have been shown to elicit epitope-specific $\mathrm{CD} 8^{+} \mathrm{T}$ cells from healthy controls that can lyse myeloid leukemic blasts [3-5]. Recent clinical studies suggest that vaccination of patients with either the HLA-A*2402-presented natural or modified epitope WT1 $1_{235-241}$ [6], the HLA-A*0201-presented epitope WT1 $1_{126-134}$ alone [7], or a combination of WT1 $1_{126-134}$ with Pr $3_{169-177}$ [8] can indeed induce leukemia-reactive $\mathrm{CD} 8^{+} \mathrm{T}$ cells that may contribute to control of solid tumor cells or leukemic blasts and induce clinical responses.

Another candidate tumor antigen is the mucin 1 protein (MUC1). Due to the aberrant glycosylation in the variable number of tandem repeat (VNTR) domain of MUC1protein in cancer cells, non-glycosylated VNTR-derived peptides $\left(\mathrm{MUC1}_{138-178}\right)$ have been described as helper epitopes for the stimulation of $\mathrm{CD}^{+}{ }^{+} \mathrm{T}$ cells [9]. VNTRderived peptides have been also described as targets for $\mathrm{CD}^{+} \mathrm{T}$ cells, although these peptides appear unusual in not fully matching defined binding motifs for the respective HLA-molecules [10]. Preclinical studies have also identified multiple HLA-A*0201 epitopes derived from regions of MUC1 outside the VNTR including $\mathrm{MUC1}_{79-87}$ [11]. MUC1-derived peptides have been shown to be presented not only by solid cancers [11], but also hematological malignancies including MM [12]. Initial clinical vaccination trials in patients with breast or ovarian cancer $[11,13]$ confirmed immunogenicity and lack of toxicity following vaccination with MUC1-derived immunogens.

In summary, WT1, Pr3, and MUC1-containing vaccines represent candidates for further clinical evaluation in patients with AML or MM. Therefore, we tested whether a vaccine composed of WT1 and Pr3 or MUC1-derived peptides can induce immunological and clinical responses.

\section{Materials and methods}

\section{Clinical protocol}

This was a non-randomized, non-blinded, controlled, bi-centric, open-label, adjuvant vaccination pilot study. Nine patients HLA*A0201 by genotyping were included. Inclusion criteria included confirmed primary or secondary AML or relapse of an AML, including RAEB/RAEB-T, IPSS score $\geq 1.5$; and minimal residual disease (MRD) (defined as $>5 \%$ $\leq 30 \%$ leukemic blasts in bone morrow). Patients with confirmed MM were also eligible if presenting with stage I or stable disease, or partial remission after cytoreductive chemotherapy. Further inclusion criteria were patients with older than $(\geq) 18$ years of age of either gender and of any race, life expectancy of at least 4 months, and adequate performance status (Karnofsky score $\geq 70 \%$ ). Systemic corticosteroid or other immunosuppressive therapies were not allowed within the last 3 months or during the study. Prior chemotherapy or radiation therapy was allowed if at least 2 weeks had elapsed between the last dose of therapy and study entry and the patient had recovered from all treatment-related toxicities. Study reagents were injected subcutaneously on days 0,14 , $28,42,56$, and 70 . Patients were vaccinated simultaneously at different locations with two different types of vaccines. AML patients received a combination of pan HLA-DR T helper cell epitope (PADRE), CpG7909, MontanideISA51 and either WT1 $1_{126-134}$ (vaccine A) or Pr3 ${ }_{169-177}$ (vaccine B). MM patients received CpG7909, MontanideISA51, and either $\mathrm{MUC1}_{79-87}$ and PADRE (vaccine C) or the oligomer $\mathrm{MUC1}_{138-178}$ (vaccine D) (Fig. 1). The oligomer in vaccine D served as source for $\mathrm{CD}^{+}$and $\mathrm{CD}^{+} \mathrm{T}$ cell epitopes. Every patient received the study substances in a dose of $1.0 \mathrm{mg}$ for each peptide, comparable to dose levels in other clinical trials [14-16], CpG7909 was administered at a final dose of $1 \mathrm{mg}$, again within the dose range of other successful clinical vaccination trials (range $0.5-8 \mathrm{mg}$ ) [17-21]. The final vaccine was freshly prepared from different compounds for each day of vaccination. PBMCs were collected at day -7 (range day $-13 / 0)$ and every second week until day 84 . Leukapheresis was performed at day 42 (range day 42/56) and 84 (range day 84/94) in order to harvest PBMCs and collected material processed and frozen immediately. The study was approved by the local ethics board, regulatory authorities and has been registered at the "Deutsche Krebstudienregister" (DKSR number 415 and 416; http://www.studien.de/includes/ studien_suchen/studie.suchen.php?PIC_CASE=1\&L).

Vaccine, peptides, pentamers, and antibodies

Clinical grade peptides were purchased from ClinalfaBachem (Weil am Rhein, Germany), and MontanideISA51 from Seppic (Köln, Germany). CpG7909 (VaxImmune ${ }^{\mathrm{TM}}$ ) 
Fig. 1 a Vaccine composition, b patient characteristics, and clinical responses after vaccination. CTCAE grading of side effects is indicated. Clinical responses were evaluated at the end of study (day 84). DTH delayed type hypersensitivity reaction, $S D$ stable disease, $P D$ progressive disease, n.d. not determined, Pretreatment treatment prior study entry
A

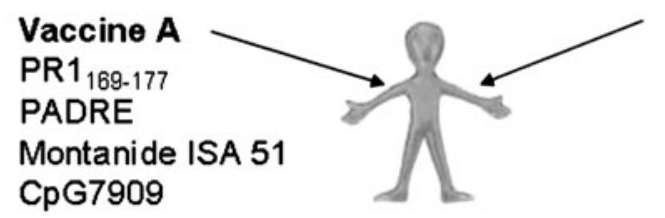

Vaccine B

WT1 $1_{126-134}$

PADRE

Montanide ISA51

CpG7909

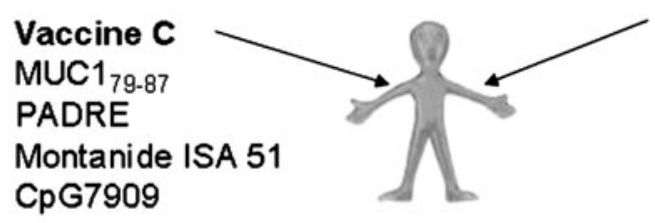

Vaccine D

MUC1 $_{138-178}$

Montanide ISA 51 CpG7909

\begin{tabular}{|c|c|c|c|c|c|c|c|c|c|}
\hline Number & Disease & $\begin{array}{l}\text { \% Blasts } \alpha \text { lgG } \\
\text { befarefafter } \\
\text { vaccination }\end{array}$ & $\begin{array}{c}\text { Pre- } \\
\text { Treatment }\end{array}$ & Vaccine & $\begin{array}{l}\text { Local } \\
\text { erythema }\end{array}$ & other & Fever & DTH & Response \\
\hline 1 & AML & $20 \% / 20 \%$ & 2 & $A+B$ & ॥ & Fatigue I & - & - & SD \\
\hline 2 & AML & $3 \% / 70 \%$ & 1 & $A+B$ & $\|-I I I$ & Fatigue I-II & III & - & PD \\
\hline 3 & AML & $30 \% / 30 \%$ & no & $A+B$ & III & $\begin{array}{l}\text { Fatigue II } \\
\text { necrosis, } \\
\text { infection III }\end{array}$ & III & $\cdot$ & SD \\
\hline 4 & AML & $20 \% / 55 \%$ & 4 & $A+B$ & ॥ & Dyspnoe III & . & . & PD \\
\hline 5 & MM & $\begin{array}{c}10 \% / 50 \% \\
21,4 / 28,9 g / 1\end{array}$ & $>4$ & $C+D$ & ॥ & - & - & - & PD \\
\hline 6 & MM & $\begin{array}{c}50 \% / 50 \% \\
26,9 / 27,1 \mathrm{~g} / 1\end{array}$ & 2 & $C+D$ & IIII & - & - & - & SD \\
\hline 7 & MM & $\begin{array}{c}20 \% / 20 \% \\
15,4 / 18,1 \mathrm{~g} / 1\end{array}$ & 2 & $C+D$ & $\|-I I I$ & - & - & - & SD \\
\hline 8 & MM & $\begin{array}{c}5 \% / 20 \% \\
10,4 / 18.4 \mathrm{~g} / 1\end{array}$ & 2 & $C+D$ & $\|-I I I$ & - & - & . & PD \\
\hline 9 & MM & $\begin{array}{c}\text { CR / CR } \\
12,7 / 14,1 \mathrm{~g} / 1\end{array}$ & 4 & $C+D$ & ॥ & Fatigue I & 1 & - & SD \\
\hline
\end{tabular}

was kindly provided by Coley pharmaceuticals $\mathrm{GmbH}$ (Düsseldorf, Germany). Peptides WT1 $1_{126-134}, \mathrm{PR} 3_{169-177}$, MUC1 $_{79-87}$, HIV-reverse transcriptase: $\mathrm{HIV}_{\mathrm{RT}}$ 476-484, HBV core $_{128-140}$, and CMVpp65 ${ }_{495-504}$, overlapping 15-mers for $\mathrm{MUC1}_{138-178}$, PADRE, PE-labeled HLAA*0201-presented $\mathrm{WT}_{126-134}, \mathrm{PR} 3_{169-177}, \mathrm{MUC1}_{79-87}$, $\mathrm{HIV}_{\mathrm{RT}}$ 476-484, and CMVpp65 495-504 pentamers were from ProImmune (Oxford, UK). Anti-CD3-Pacific Blue, anti-CD4-APC Alexa Fluor 750, anti-CCR7-PE-cy7, anti-CD27-APC Alexa Fluor 750, anti-PD-1-APC, antiFoxP3-APC (including anti-human Foxp3 Staining Set), anti-TNF $\alpha$-PE Cy7, anti-IL4-PE Cy7, anti-IL10-PE, were obtained from Invitrogen (Paisley, UK); anti-CD8-PercP, CD86-PE, anti-CD25-FITC, anti-CD127-PE Cy7, antiIFN $\gamma$-FITC, and anti-IL2-APC from BD Biosciences (Erembodegem, Belgium); and anti-CD303-FITC (BDCA2) from Miltenyi Biotec (Gladbach, Germany). Flow cytometry was performed on an LSR II flow cytometer (BD Biosciences) using FacsDiva software (BD Biosciences).
Pentamer staining and functional $\mathrm{T}$ cell assays

Pentamer staining and functional $\mathrm{T}$ cell assays were performed as described recently [4, 5, 22-24]. In brief, $\sim 1 \times 10^{6}$ PBMCs were incubated with pentamer for $30 \mathrm{~min}$, then directly conjugated antibodies were added for $20 \mathrm{~min}$ at $4{ }^{\circ} \mathrm{C}$ in order to specify $\mathrm{T}$ cell phenotype (CD3Pacific Blue, CD27-APC-Alexafluo 750, PD-1 APC, and CD8-PercP, CCR7-PE-cy7). Cells were washed with PBS and resuspended in FACS buffer $(0.1 \% \mathrm{BSA}+0.1 \% \mathrm{Na}-$ azide in PBS) for FACS analysis. Gating for all pentamer stainings were standardized within individual samples to arrive at a fully comparative datasets. In order to test background staining for individual pentamers, $10^{6}$ PBMCs derived from five HLA-A*0201-positive but CMV- and HIV-negative healthy individuals were co-incubated with individual pentamers and an anti-CD8 antibody and analyzed by flow cytometry. Unspecific staining was thereby determined for all pentamers as $\leq 0.05 \%$ of $\mathrm{CD}^{+} \mathrm{T}$ cells 
(data not shown). To assess the sensitivity of pentamer staining to detect vaccine-reactive $\mathrm{T}$ cells with intermediate avidity and low frequency, we took advantage of previous work from our laboratory with intermediate avidity WT1 $126-134$-specific T cells $[4,23]$. These data and titration of a WT1 $1_{126-134}$-specific T cell clone into $10^{6} \mathrm{CD}^{+} \mathrm{T}$ cells (Supplementary Fig. 4) demonstrate a highly reproducible and specific pentamer staining for intermediate avidity $\mathrm{T}$ cell lines and clones with frequencies $\geq 0.10 \%$. Intracellular cytokine (ICC) assay was performed as described recently [4]. In brief, $\sim 1 \times 10^{6} \mathrm{PBMCs}$ were stimulated with the indicated peptide $(10 \mu \mathrm{g} / \mathrm{ml})$ and Brefeldin A (GolgiPlug $^{\mathrm{TM}}$, BD) $(1 \mu \mathrm{l} / \mathrm{ml})$ for $6 \mathrm{~h}$ at $37^{\circ} \mathrm{C}$. After $6 \mathrm{~h}$, cells were washed and surface antibodies were added: antiCD3-Pacific Blue, anti-CD4-APC Alexa Fluor 750, antiCD8-PercP. Cells were incubated for $20 \mathrm{~min}$ at $4^{\circ} \mathrm{C}$ and washed with PBS. Cells were fixed and permeabilized with lysing and permeabilizing solution (BD FACS ${ }^{\mathrm{TM}}$ ). Next, anti-TNF $\alpha$-PE Cy7, anti-IFN $\gamma$-FITC, and anti-IL2-APC or anti-IL4-PE Cy7 and anti-IL10-PE were added. Gating for all ICC assays was standardized within individual samples to arrive at a fully comparative datasets. Thereby, background signal for TNF $\alpha$, IFN $\gamma$, and IL2 cytokine secretion was tested in 2 HLA-A*0201-positive HIV and CMVnegative healthy individuals. $\mathrm{CD}^{+}{ }^{+}$or $\mathrm{CD}^{+}$cytokinesecreting cells were detected in $<0.1 \%$ of cells (data not shown), thus the detection threshold was determined as $0.1 \%$. In vitro expansion assays were performed as described recently [23]. In brief, $1 \times 10^{6} \mathrm{PBMCs} /$ sample were stimulated with $1 \mu \mathrm{g} / \mathrm{ml}$ peptides $\mathrm{WT}_{126-134}$, PR3 ${ }_{169-177}, \mathrm{MUC1}_{79-87}$, overlapping 15-mer $\mathrm{MUC1}_{138-164}$, overlapping 15-mer $\mathrm{MUC1}_{153-178,}, \mathrm{HIV}_{\mathrm{RT}}{ }_{476-484}$ or CMVpp65 $495-503$, together with $50 \mathrm{U} / \mathrm{ml}$ IL2 (Chiron, Emeryville, CA, USA), for 1 week at $37^{\circ} \mathrm{C}$. After 1 week, a 6-h stimulation followed by an ICC assay was performed as described above. $\mathrm{T}$ cell clones with specificity for WT $1_{126-134}$ have been generated as described recently [4, $5,23]$. A twofold change in frequency of antigen-specific $T$ cells was considered as vaccine-induced, an arbitrary threshold used in multiple vaccination studies to define vaccine-specific immune responses [7, 8].

\section{Results}

Study design and patient characteristics

The study was designed to induce leukemia-/MM-reactive $\mathrm{T}$ cells with a polyvalent vaccine composed of HLAA*0201-presented peptides $\mathrm{WT}_{126-134}$ (vaccine A) and Pr3 169-177 (vaccine B) (AML patients) or $\mathrm{MUC1}_{79-87}$ (vaccine $\mathrm{C}$ ) and those derived from $\mathrm{MUC1}_{138-178}$ (vaccine D) (MM patients) (Fig. 1). The vaccine included either a
PADRE, which was engineered to bind common HLA-DR molecules with high affinity [25, 26], or a MUC1 oligomer [9] to induce $\mathrm{CD}^{+}$helper $\mathrm{T}$ cells. To enhance immunogenic antigen-presentation, CpG7909 (VaxImmune ${ }^{\mathrm{TM}}$ ), a single-stranded oligodeoxynucleotide (ODN) that activates plasmacytoid dendritic cells through toll-like receptor (TLR) 9 triggering, and has been reported to increase tumor-reactive $\mathrm{CD}^{+} \mathrm{T}$ cells upon vaccination in melanoma patients [17], was also included. Four AML (vaccine $\mathrm{A}+\mathrm{B}$ ) and $5 \mathrm{MM}$ (vaccine $\mathrm{C}+\mathrm{D})$ patients were simultaneously vaccinated every 2 weeks until a total of six vaccinations (Fig. 1).

\section{Clinical outcome and side effects}

During the study observation period, two of four AML patients had progressive disease according to IWG criteria [27]; two of five MM patients progressed (EBMT, IBMTR and ABMTR criteria [28]); and, all other patients had stable disease at study day 84 (Fig. 1b). As all patients have not been progressive before vaccination, and also no late responses were observed, we concluded that no clinical responses were observed [7]. After vaccination, all patients had inflammation at the injection sites (grades II-III toxicity according to CTCAE: Cancer Therapy Evaluation Program, Common Terminology Criteria for adverse Events, Version 3.0). Four patients experienced mild fatigue (grades I-II) and three had fever (grades I-III) (Fig. 1b). To assess for vaccine-specific $\mathrm{T}$ cell responses, a delayed type hypersensitivity (DTH) test was performed with the following peptides from the vaccine at study days 2, 44, and 86: PADRE (all patients); WT1 $1_{126-134}$, PR3 169-177 (AML patients); and $\mathrm{MUC1}_{79-87}$ and MUC1 $_{138-178}$ (MM patients). None of the patients had a positive DTH test with any peptide at any time (Fig. 1b).

Vaccine-specific $\mathrm{CD}^{+}{ }^{+} \mathrm{T}$ cells (VST) cannot be recruited by vaccination and rather decline

To investigate if vaccination of the four AML patients with the HLA-A*0201-binding peptides WT1 $1_{126-134}$, PR3 ${ }_{169-177}$, or the five MM patients with the $\mathrm{MUC1}_{79-87}$ peptide increased the frequency of VST, collected PBMCs were incubated with HLA-A*0201 restricted WT1 $1_{126-134}$ and PR3 $169-177$ pentamers if vaccinated with vaccines $A$ and $\mathrm{B}$ (4 patients with $\mathrm{AML}$ ) and $\mathrm{MUC1}_{79-87}$ pentamers if vaccinated with vaccines $\mathrm{C}$ and $\mathrm{D}$ (5 patients with $\mathrm{MM}$ ) [4, 5, 23]. As a negative control, an $\mathrm{HIV}_{\mathrm{RT} 476-484}$ pentamer was used; and as a positive control, a CMVpp65 $495-503$ pentamer was used. In six of nine patients, pp65 $495-503^{-}$ specific $\mathrm{T}$ cells were detectable prior to vaccination and through study day 84 (range $0.15-3.30 \%$ ) (CMVpos group) and frequencies did not significantly differ when 
comparing patients before and after vaccination (Fig. 2a). Four of five MM patients had pre-existing $\mathrm{MUC1}_{79-87}$ pentamer-positive $\mathrm{CD} 8^{+} \mathrm{T}$ cells (range $0.15-0.30 \%$ ) and one AML patient had pre-existing WT1 $1_{126-134}$ pentamerpositive $\mathrm{CD}^{+} \mathrm{T}$ cells $(0.15 \%$, Supplementary Fig. 1) (defined as VST group). Thus, four patients had no VST prior vaccination (NoVST group). When comparing the frequency of VST in the group of patients with NoVST before and after vaccination, no increase in VST was observed. In contrast, a slight but significant decline in pentamer-positive VST (AML and MM patients, $p=0.02$ ) was observed within the VST group $(n=5$ patients) after vaccination while the frequency of pp65 $495-503$-specific $\mathrm{T}$ cells did not change significantly (Fig. 2a), e.g., in patient 4 with pre-existing $\mathrm{WT}_{126-134}$ pentamer-positive $\mathrm{CD} 8^{+} \mathrm{T}$ cells $(0.15 \%)$ the $\mathrm{WT}_{126-134}$ pentamer-positive $\mathrm{CD}^{+} \mathrm{T}$ cells were no longer detectable at all other time points after vaccination including days 42 and 84 (Fig. 2a, Supplementary Fig. 1). In addition, no VST were observed in the bone marrow of patients before or 84 days after vaccination (data not shown).

To assess if the phenotype of persisting pentamer-positive $\mathrm{CD} 8^{+} \mathrm{T}$ cells changed from naïve/central memory $\left(\mathrm{CD} 27^{+} / \mathrm{CCR} 7^{+}\right)$to effector memory/effector $\left(\mathrm{CD} 27^{-} /\right.$ $\mathrm{CCR}^{-}$) after vaccination, $\mathrm{CD} 8^{+} \mathrm{T}$ cells were stained with pentamer, anti-CD27 and anti-CCR7 at day -7 and 42 . Percentage of $\mathrm{CD} 27^{-} / \mathrm{CCR} 7^{-}$pentamer-positive $\mathrm{T}$ cells was compared before and after vaccination and indeed only for MUC1 $1_{79-87}$ but not for pp65 $5_{495-503}$ pentamer-positive T cells a significant increase ( $t$ test $p=0.03)$ in the $\mathrm{CD} 27^{-}$/ $\mathrm{CCR}^{-}{ }^{-}$cell population was observed suggesting that naïve/ central memory cells indeed had become effector memory or effector cells after vaccination (Fig. 2b). However, VST apparently failed to proliferate and were rather depleted (Fig. 2a). The pentamer-positive cells were also stained with anti-PD1, a marker of T cell exhaustion [29], but none of the pentamer-positive cells exhibited substantial PD1expression (data not shown).

\section{WT1- and MUC1-specific CD8 ${ }^{+} \mathrm{T}$ cells}

are functionally impaired

The failure of pre-existing pentamer-positive WT1- and MUC1-specific T cells to expand after vaccination could be either a consequence of complete anergy, with an absolute inability to respond to antigen, or a selective inability to proliferate [30]. Therefore, PBMCs of patients within the VST group were stimulated for $6 \mathrm{~h}$ with $\mathrm{WT} 1_{126-134}$ and PR3 ${ }_{169-177}$ peptides (AML patients) and MUC1 $1_{79-87}$ peptide and overlapping 15-mers derived from the MUC1 $1_{138-178}$ oligomer (MM patients). Although, all tested patients had pre-existing $\mathrm{WT}_{126-134}$ or $\mathrm{MUC1}_{79-87}$ pentamer-positive cells (Fig. 2a, b), we failed to detect specific
TNF $\alpha$, IFN $\gamma$, o rIL2 production by ICC in response to respective antigens before and after vaccination (all $<0.1 \%$ ), suggesting that the detectable WT1-/MUC1pentamer-positive $\mathrm{CD} 8^{+} \mathrm{T}$ cells were not functional in vivo prior to vaccination, and that function could not be rescued by vaccination. Also 7 days of stimulation of PBMCs from selected patients with $\mathrm{MUC1}_{79-87}$, and two pools of overlapping 15-mers derived from $\mathrm{MUC1}_{138-164}$ and $\mathrm{MUC1}_{153-178}$ (MM patient), pp65 ${ }_{495-503}$, and $\mathrm{HIV}_{\mathrm{RT}}$ 476-484, did neither result in any pentamer-positive $(<0.05 \%$, data not shown) nor functional VST (Table 1) after vaccination, while pp65 $495-503^{-}$-specific $\mathrm{T}$ cells did not change in frequency (Table 1). Only in one AML patient (patient 1 ) who had no pre-existing vaccine-reactive T cells by pentamer staining, we could generate $0.4 \% \mathrm{CD}^{+} \mathrm{T}$ cells with specific IFN $\gamma$ production against $\mathrm{WT} 1_{126-134}$ prior to vaccination which were, however, no longer detectable after vaccination (Table 1; Supplementary Fig. 2) in line with the observation that vaccination decreased the number of pentamer-positive VST (Fig. 2a).

Expansion of PADRE-specific CD4 ${ }^{+} \mathrm{T}$ helper cells which do not substantially produce IL2

All vaccines contained a potential $\mathrm{CD} 4^{+} \mathrm{T}$ helper epitope, either the 'pan HLA-DR T helper epitope' PADRE or $\mathrm{MUC1}_{138-178}$, to induce $\mathrm{CD} 4^{+} \mathrm{T}$ helper cells and potentially improve the generation and persistence of WT1-/ Pr3-/MUC1-specific $\mathrm{CD}^{+} \mathrm{T}$ cells. In five of eight patients, PADRE-specific $\mathrm{CD} 4^{+} \mathrm{T}$ cells were detected prior to vaccination (range $0.20-0.40 \%$ of $\mathrm{CD}^{+} \mathrm{T}$ cells) that produced either IFN $\gamma$ or TNF $\alpha$, but no IL2, IL4, or IL10 production was detectable (Fig. $2 \mathrm{c}$ and data not shown for IL4 and IL10). A significant increase in IFN $\gamma$ producing PADRE-specific $\mathrm{CD}^{+}{ }^{+} \mathrm{T}$ cell responses was detected after vaccination. Also higher amounts of TNF $\alpha$ producing PADRE-specific $\mathrm{T}$ cells were observed, although not significant. $\mathrm{T}$ cells did not produce IL2 (Fig. 2c). In Patient 7, a two- to fourfold induction of

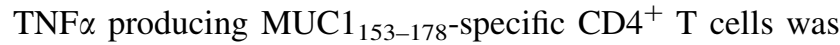
observed $(<0.1 \%$ day $-7,0.4 \%$ day $42,0.2 \%$ day 84$)$, and, again, no IL2 production could be measured (Supplementary Table 1 ).

In order to test more thoroughly if PADRE stimulation could lead to induction of IFN $\gamma$ and TNF $\alpha$-secreting $\mathrm{CD} 4^{+}$ $\mathrm{T}$ cells that lack the ability to produce detectable amounts of IL2, PBMCs were stimulated for 1 week with helper peptides. In all four patients, PADRE-specific $\mathrm{T}$ cells were detectable prior to vaccination (frequency $0.2-2.0 \%$ ) by ICC and produced either IFN $\gamma$ or both IFN $\gamma$ and TNF $\alpha$. More importantly, in two patients they also produced IL2 (Table 2). After vaccination, the frequency of IFN $\gamma$ - and/or $\mathrm{TNF} \alpha$-secreting cells increased twofold until day 42 or 84 
Fig. 2 Decrease in vaccinespecific T cells (VST) and increase in regulatory $\mathrm{CD} 4^{+} \mathrm{T}$ cells after vaccination. a Pentamer-positive $\mathrm{CD} 8^{+} \mathrm{T}$ cells before (day -7 ) and after (days 14-84) vaccination in all patients $(n=9)$. CMV seropositive (CMVpos) group $n=6$, sero-negative (CMVneg) group $n=3$, VST before vaccination group (VST) $n=5$, no VST before vaccination group (NoVST) $n=4$, HIVreverse-transcriptase-peptide (HIVRT). b Pentamer-positive $\mathrm{CD}^{+} \mathrm{T}$ cells were gated and percentages of pentamerpositive effector memory/ effector $\mathrm{T}$ cells $\left(\mathrm{CD} 27^{-}\right.$/ $\mathrm{CCR}^{-}$) calculated before vaccination and at day 42 after vaccination. c Percent cytokine producing PADRE-specific $\mathrm{CD}^{+} \mathrm{T}$ cells as measured by ICC. d Flow cytometry analysis of patient-derived PBMC samples collected prior to vaccination and at day 42 and 84. Cells were incubated with anti-CD3, anti-CD8, anti-CD4, anti-CD25, anti-CD127, and anti-FoxP3. Regulatory phenotype is defined as: $\mathrm{CD} 25^{+} \mathrm{CD} 127^{\text {low }} \mathrm{FoxP}^{+} \mathrm{CD} 4^{+}$

$\mathrm{T}$ cells. The dotted line represents the threshold of a more then twofold increase of $\mathrm{CD} 25^{+} \mathrm{CD} 127^{\text {low }} \mathrm{FoxP}^{+} \mathrm{CD} 4^{+}$ $\mathrm{T}$ cells after vaccination. n.p. not possible
A

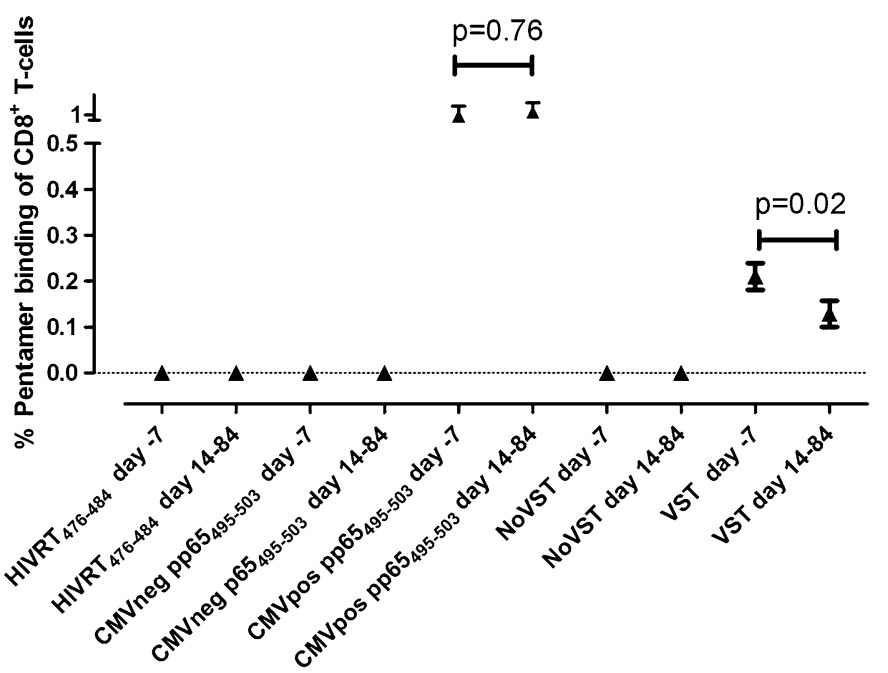

B

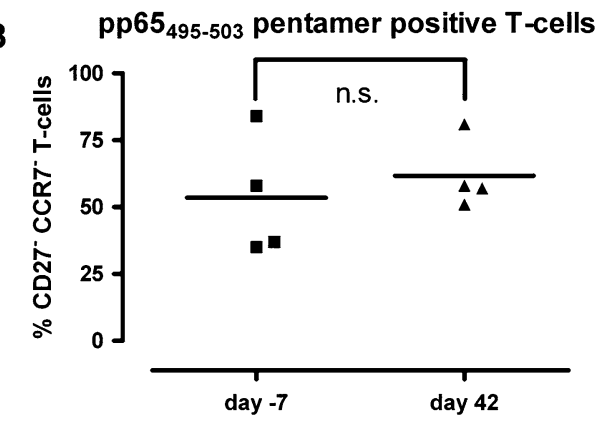

MUC1 $_{79-87}$ pentamer positive T-cells

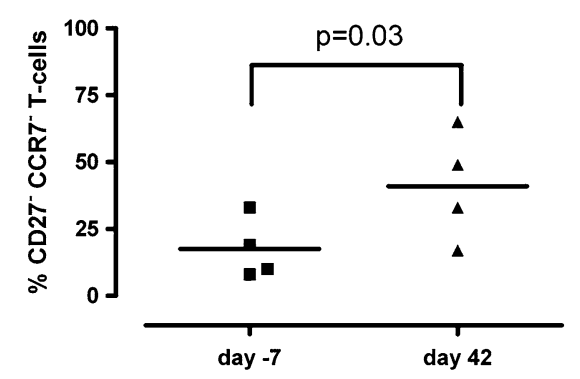

C

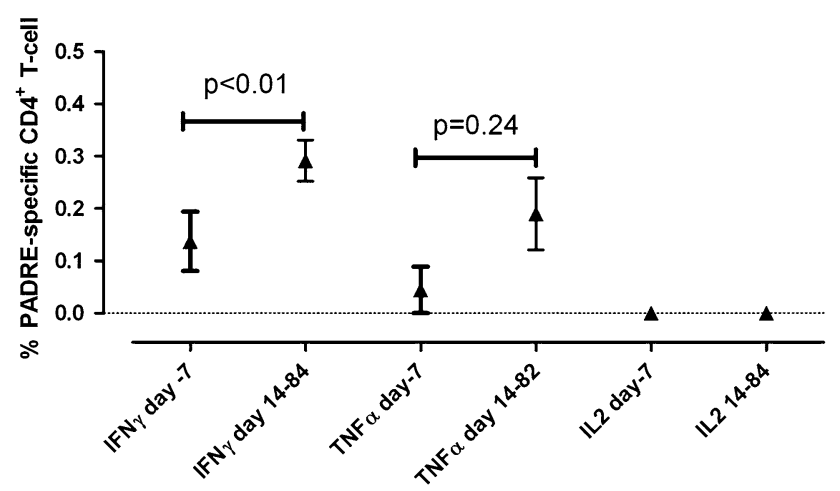

Fold increase $\mathrm{CD} 4^{+} \mathrm{CD} 25^{+} \mathrm{CD} 127^{\text {low }} \mathrm{FoxP} 3^{+} \mathrm{T}$ cells

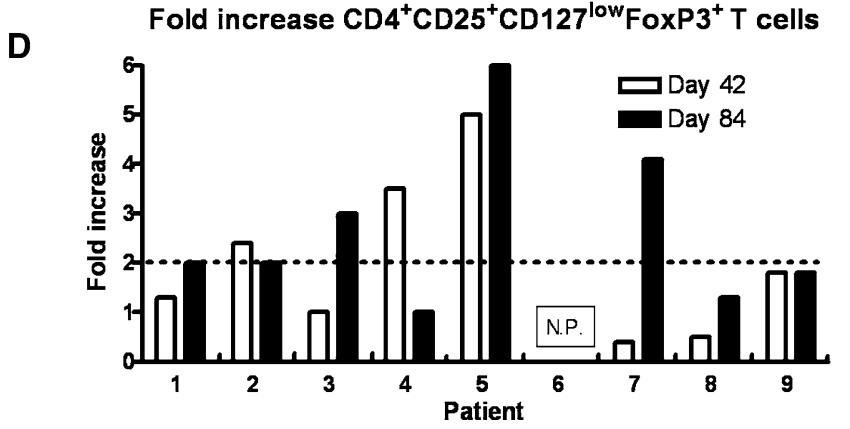

after vaccination (range 2.8-17.8-fold increase) (Table 2; Supplementary Fig. 3). Although the number of PADREspecific IFN $\gamma$ and/or $\mathrm{TNF} \alpha$ producing $\mathrm{CD}^{+} \mathrm{T}$ cells increased substantially after vaccination in all patients, preexisting IL2 producing PADRE-specific $\mathrm{CD}^{+}{ }^{+} \mathrm{T}$ cells in patients were not found in greater numbers (Table 2). 
Table 1 Cytokine production of in vitro expanded leukemia-/MM-/virus-specific CD8 ${ }^{+} \mathrm{T}$ cells before and after vaccination

\begin{tabular}{|c|c|c|c|c|c|c|c|c|c|}
\hline & \multicolumn{9}{|c|}{ After 7 days in vitro re-stimulation of $\mathrm{CD}^{+} \mathrm{T}$ cells } \\
\hline & \multirow{2}{*}{$\begin{array}{l}\text { Peptide } \\
\text { Day }\end{array}$} & \multicolumn{2}{|c|}{$\mathrm{HIV}_{\mathrm{RT} 476-134}$} & \multicolumn{2}{|c|}{ pp65 $495-503$} & \multicolumn{2}{|c|}{ WT1 $1_{126-134}$} & \multicolumn{2}{|c|}{$\operatorname{Pr} 3_{169-177}$} \\
\hline & & -7 & $42 \& 84$ & -7 & $42 \& 84$ & -7 & $42 \& 84$ & -7 & $42 \& 84$ \\
\hline \multirow[t]{3}{*}{1} & IFNg & $<0.1$ & $<0.1$ & 24.6 & $22.3^{\mathrm{a}}$ & 0.4 & $<0.1$ & $<0.1$ & $<0.1^{\mathrm{a}}$ \\
\hline & $\mathrm{TNFa}$ & $<0.1$ & $<0.1$ & 4.0 & $3.9^{\mathrm{a}}$ & $<0.1$ & $<0.1$ & $<0.1$ & $<0.1^{\mathrm{a}}$ \\
\hline & IL2 & $<0.1$ & $<0.1$ & 0.4 & $0.2^{\mathrm{a}}$ & $<0.1$ & $<0.1$ & $<0.1$ & $<0.1^{\mathrm{a}}$ \\
\hline \multirow[t]{3}{*}{2} & IFNg & $<0.1$ & $<0.1^{\mathrm{a}}$ & 0.7 & $0.3^{\mathrm{a}}$ & $<0.1$ & $<0.1^{\mathrm{a}}$ & $<0.1$ & $<0.1^{\mathrm{a}}$ \\
\hline & $\mathrm{TNFa}$ & n.p. & $<0.1^{\mathrm{a}}$ & n.p. & $0.3^{\mathrm{a}}$ & n.p. & $<0.1^{\mathrm{a}}$ & n.p. & $<0.1^{\mathrm{a}}$ \\
\hline & IL2 & $<0.1$ & $<0.1^{\mathrm{a}}$ & 0.2 & $<0.1$ & $<0.1$ & $<0.1$ & $<0.1$ & $<0.1^{\mathrm{a}}$ \\
\hline \multirow[t]{6}{*}{3} & IFNg & $<0.1$ & $<0.1^{\mathrm{a}}$ & $<0.1$ & $<0.1^{\mathrm{a}}$ & $<0.1$ & $<0.1^{\mathrm{a}}$ & $<0.1$ & $<0.1^{\mathrm{a}}$ \\
\hline & $\mathrm{TNFa}$ & n.d. & n.d. & n.d. & n.d. & n.d. & n.d. & n.d. & n.d. \\
\hline & IL2 & $<0.1$ & $<0.1^{\mathrm{a}}$ & $<0.1$ & $<0.1^{\mathrm{a}}$ & $<0.1$ & $<0.1^{\mathrm{a}}$ & $<0.1$ & $<0.1^{\mathrm{a}}$ \\
\hline & \multicolumn{9}{|c|}{ After 7 days in vitro re-stimulation of $\mathrm{CD}^{+} \mathrm{T}$ cells } \\
\hline & Peptide & \multicolumn{2}{|c|}{$\mathrm{HIV}_{\mathrm{RT} 476-134}$} & \multicolumn{2}{|c|}{ 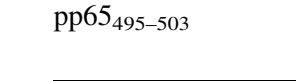 } & \multicolumn{2}{|c|}{$\mathrm{MUC1}_{79-87}$} & \multicolumn{2}{|c|}{$\begin{array}{l}\text { MUC1 }_{153-178} \\
\text { MUC1 }_{138-164}\end{array}$} \\
\hline & Day & \multicolumn{2}{|l|}{-7} & \multicolumn{2}{|c|}{$42 \& 84$} & \multicolumn{2}{|l|}{-7} & \multicolumn{2}{|c|}{$42 \& 84$} \\
\hline \multirow[t]{3}{*}{9} & $\mathrm{IFNg}$ & $<0.1$ & $<0.1$ & $<0.1$ & $<0.1^{\mathrm{a}}$ & $<0.1$ & $<0.1$ & $<0.1$ & $<0.1$ \\
\hline & $\mathrm{TNFa}$ & $<0.1$ & $<0.1$ & $<0.1$ & $<0.1^{\mathrm{a}}$ & $<0.1$ & $<0.1$ & $<0.1$ & $<0.1$ \\
\hline & IL2 & $<0.1$ & $<0.1$ & $<0.1$ & $<0.1^{\mathrm{a}}$ & $<0.1$ & $<0.1$ & $<0.1$ & $<0.1$ \\
\hline \multicolumn{2}{|c|}{ Pre-existing } & $0 / 4$ & & $2 / 4$ & & $1 / 4$ & & $0 / 4$ & \\
\hline \multicolumn{2}{|c|}{ Induction } & & $0 / 4$ & & $0 / 4$ & & $0 / 4$ & & $0 / 4$ \\
\hline \multicolumn{2}{|c|}{ Loss } & & $0 / 4$ & & $0 / 4$ & & $1 / 4$ & & $0 / 4$ \\
\hline
\end{tabular}

Intracellular cytokine production (ICC) 7 days after antigen-specific in vitro stimulation. Bold numbers indicate the specific detection of cytokine-secreting $\mathrm{CD}^{+} \mathrm{T}$ cells; italic numbers indicate a twofold change when compared with day -7 . If for day $42 \& 84$ only one value is indicated then measured values are identical

n.d. not determined due to lack of material

${ }^{\text {a }}$ Only one of the indicated time points was analyzed

Thus, IL2 production appeared to be impaired in PADREspecific $\mathrm{CD} 4^{+} \mathrm{T}$ cells after vaccination.

Increase of $\mathrm{CD} 4^{+} \mathrm{T}$ cells with a regulatory phenotype after vaccination

It has been reported that CpG7909 can stimulate plasmacytoid dendritic cells and thereby increase the number of $\mathrm{CD}^{+} \mathrm{T}$ cells with a regulatory phenotype and function in vitro [31] and in vivo [32] in mice, which could consequently inhibit the success of a vaccine $[32,33]$. To investigate if the vaccination regimen influenced the frequency or maturation of plasmacytoid dendritic cells as reported recently (defined as CD303- and CD86positive $[21,34])$ or the frequency of regulatory $\mathrm{T}$ cells in the peripheral blood, patient-derived PBMC obtained at day $-7,42$, and 84 were stained with anti-CD303 (BDCA-2) antibody, a single marker for plasmacytoid dendritic cells [35], anti-CD86, anti-CD25, anti-FoxP3, and anti-CD127, and analyzed by flow cytometry. The amount of both, immature $\left(\mathrm{CD} 86^{-}\right)$and mature $\left(\mathrm{CD} 86^{+}\right)$ anti-CD303-positive (plasmacytoid dendritic) cells did not increase more then twofold over 84 days (range plasmacytoid dendritic cells $<0.1-0.4 \%$ of total PBMCs) (Supplementary Table 2). However, five out of eight patients showed a more than twofold increase in $\mathrm{CD} 25^{+}$ FoxP3 ${ }^{+} \mathrm{CD} 127^{\text {low }} \mathrm{CD}^{+} \mathrm{T}$ cells in one or both time points after vaccination (range 2.4-6.0-fold increase) (Fig. 2d).

\section{Discussion}

The main findings of our studies are that in contrast to multiple other vaccination phase I studies using similar antigens [7, 8, 11, 13, 36, 37] pre-existing WT1-/MUC1specific $\mathrm{T}$ cells in advanced stage cancer patients (a) neither proliferated nor secreted cytokines upon peptide stimulation and (b) were rather depleted than rescued after vaccination. 
Table 2 Cytokine production of PADRE-specific $\mathrm{CD}^{+} \mathrm{T}$ cells before and after vaccination

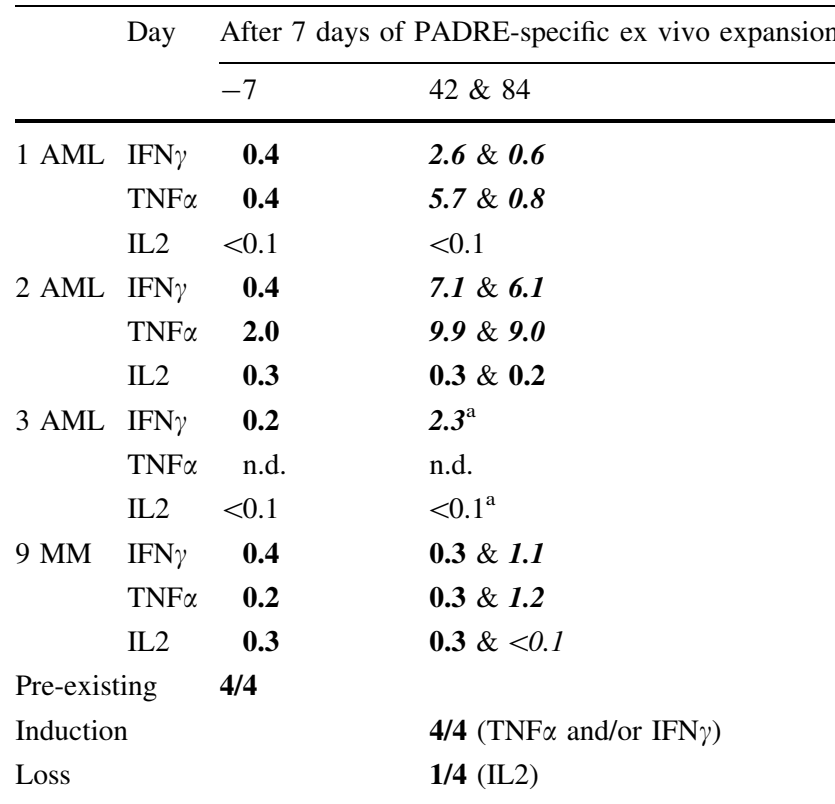

PADRE-specific cytokine production of $\mathrm{CD}^{+}{ }^{+} \mathrm{T}$ cells expression was measured by intracellular cytokine production assay (ICC) 7 days after PADRE-specific stimulation. Bold numbers indicate the specific detection of cytokine-secreting $\mathrm{CD} 4^{+} \mathrm{T}$ cells; italic numbers indicate a twofold change when compared with day -7

n.d. not determined due to lack of material

${ }^{a}$ Only 1 of the indicated time points was analyzed

Non-functional but more importantly also functional WT1/MUC1-reactive $\mathrm{T}$ cells were observed in multiple patients before but not after vaccination. We also did not detect vaccine-reactive $\mathrm{T}$ cells in the bone marrow, a preferential homing side of memory $\mathrm{T}$ cells [38]. Thus, vaccination could have induced anergy or exhaustion of pre-existing VST. Anergy and exhaustion of tumor-reactive $\mathrm{T}$ cells in cancer patients can occur either from chronic or suboptimal antigen stimulation or from other immunosuppressive events supported by tumor cells or their microenvironment [39]. Exhaustion, anergy or deletion of reactive $\mathrm{T}$ cells has also been reported after repetitive injections of high doses of peptide i.p. [40], after a single low dose of peptide s.c. [41] or after introduction of antigens to immature dendritic cells through the endocytic receptor DEC-205 in mice [42].

The differences observed in our clinical study when compared with other vaccine trials might also reflect the type of underlying disease in vaccine recipients. Regulatory mechanisms potentially active in cancer patients that might be increasingly operative in patients with AML include myeloid suppressor cells, which can secrete inhibitory cytokines [43] or depletion of tryptophan by leukemic blasts [44]. However, recent clinical phase I studies suggest that vaccination of AML patients with
WT1-derived peptides can induce leukemia-reactive CD8 ${ }^{+}$ $\mathrm{T}$ cells in patients with low and high leukemia load [6-8] making it unlikely that the type or stage of disease alone were responsible for the absence of immunogenicity of the vaccine tested in our study.

Epitope dominance and competition for HLA-class Ipresented antigens on dendritic cells have been suggested as a mechanism, which can impair immune responses to certain antigens [45]. However, a successful combined vaccination with WT1 and Pr3 has been reported [8] making it unlikely that the combination of antigens hampered the success of our vaccine. Furthermore, HLA-class I-presented antigens were injected at different sites in order to circumvent the competition for antigen-loaded dendritic cells.

Multifunctional $\mathrm{T}$ cells are generally required to control viral infections or tumors [46]. Thus, $\mathrm{T}$ cells need to not only produce effector cytokines, e.g., TNF $\alpha$, but also other cytokines such as IL2 that are essential for promoting T cell proliferation. The inability to detect IL 2 production by PADRE-specific $T$ helper cells could have impaired the induction of $\mathrm{CD} 8^{+} \mathrm{T}$ cells or even supported depletion of MUC1/WT1-reactive $\mathrm{CD}^{+} \mathrm{T}$ cells. It has indeed been reported that IL2 production of PADRE-specific CD4 ${ }^{+} \mathrm{T}$ cells is crucial to induce potent $\mathrm{CD} 8^{+} \mathrm{T}$ cell responses [47], and induction of IL2-producing PADRE-specific T cells has been selectively achieved when PADRE was directly loaded onto dendritic cells. This suggests that the presentation of the delivered helper antigen by professional antigen-presenting cells was suboptimal in our clinical trial.

To improve delivery and presentation of tumor antigens, clinical trials targeting MUC1, WT1 or Pr3 have taken advantage of peptide-pulsed dendritic cells [11] or administration/production of GM-CSF [7, 8, 13], although other studies have used no additional stimuli [6]. In all these studies, MHC class I-restricted vaccine-specific T cell responses could be enhanced. In our study, the vaccine contained CpG7909, which can activate plasmacytoid dendritic cells through TLR9 [48]. Successful vaccination trials with WT1 have been reported with myeloid dendritic cells [37] and the difference in the type of dendritic cell might have indeed hampered the immunological outcome of our trial. However, CpG7909 has been also reported to increase Melan-A- or NY-ESO-1-specific $\mathrm{CD} 8^{+} \mathrm{T}$ cells in combination with a peptide vaccine in patients at dose levels $0.5-2.5 \mathrm{mg}$, which is comparable to the $1 \mathrm{mg}$ dose used in our trial $[17,19,20]$. At higher dose levels of 6-8 mg without providing exogenous antigens, CpG7909 has been reported to boost pre-existing $\mathrm{CD}^{+} \mathrm{T}$ cells with specificities against various melanoma-associated antigens, to induce an activated phenotype in plasmacytoid dendritic cells, and to enhance natural killer cell cytotoxicity [18, 
21]. In our clinical trial, we could not detect an increase in activated phenotype of plasmacytoid dendritic cells, which could be a consequence of the lower CpG7909 dose used in our trial. An insufficient maturation of professional antigen-presenting cells resulted most likely in a suboptimal antigen-presentation and could thereby explain the observed partial deletion of pre-existing tumor-specific $\mathrm{T}$ cells after vaccination [42].

A reduced $\mathrm{CD}^{+} \mathrm{T}$ cell response has also been observed in mice after vaccination with a TLR9 agonist [49]. We observed in a similar mouse model that although the combination of MontanideISA51 and CpG7909 has no negative impact on humoral immune responses, this combination has in particular with low $\mathrm{CpG}$ doses a negative impact on $\mathrm{CD}^{+} \mathrm{T}$ cell responses (unpublished results $\mathrm{RD}$ Weeratna, A Vicari, HL Davis). Thus, the negative impact on $\mathrm{CD} 8^{+} \mathrm{T}$ cell responses observed in the current study with this adjuvant combination is most likely due to the use of a low $\mathrm{CpG}$ concentration (1 mg when compared with 2.5-8 mg) [17-21] with suboptimal activation of antigenpresenting cells and a subsequently weakened Th1 response.

Finally, it has also been reported that CpG7909 can induce regulatory $\mathrm{T}$ cells in vitro [31] and that regulatory $\mathrm{T}$ cells can dampen an immune response after vaccination in men [50]. We did observe in our cohort an increase in $\mathrm{T}$ cells with a regulatory phenotype after vaccination. However, as three out of five patients with a twofold increase in regulatory $\mathrm{T}$ cells also had disease progression, we cannot entirely exclude that the increase in regulatory $\mathrm{T}$ cells was at least partially a consequence of disease progression or other physiological changes rather than a consequence of the vaccine [51]. An increase in regulatory $\mathrm{T}$ cells has also been observed in other vaccination trials [52] and a successful vaccination in AML or MM patients has been associated with a decrease in regulatory $\mathrm{T}$ cells [53]. Thus, regardless of the underlying mechanism, the increase in $\mathrm{T}$ cells with a regulatory phenotype might have further hampered the success of the vaccine, particular in the context that antigen delivery to professional antigen-presenting cell may have been sub-optimal.

In summary, we demonstrate that in contrast to our intention vaccination with WT1-, Proteinase3- and MUC1derived peptides in combination with MontanideISA51 and CpG7909 rather hampers $\mathrm{CD}^{+} \mathrm{T}$ cell responses in men. To our knowledge all so far published phase I studies with here used antigens [7, 8, 11, 13, 36, 37] included usually small numbers of patients (10-20) and reported the induction of VST after vaccination. This might partially reflect a strong bias towards the publication of positive clinical trials but could also reflect differences in the adjuvant used in our clinical trial. In this context, we speculate that the composition of the adjuvant can be of utmost importance for the success of a vaccine, e.g., suboptimal concentrations of $\mathrm{CpG}$ or combinations of different adjuvants with well defined immunogenic antigens can be detrimental, need to be avoided; and recently reported superior adjuvants $[7,8,11,13,36,37]$ should preferentially be used. However, we cannot entirely exclude confounding factors, e.g., due to the small sample size and physiological variations in immunological analyses of small patient cohorts, which are also a substantial problem for previously published clinical trials with a positive outcome. Considering that 1/3 (57 of 147) of ongoing peptide vaccination trails currently registered at clinicaltrials.gov use Montanide and that an increasing amount of trials take advantage of $\mathrm{CpG}$ or the combination of $\mathrm{CpG}$ and Montanide, our data need to be taken into consideration for the design of ongoing and planned immunotherapy protocols.

Acknowledgments We thank the members of the Tumorvakzinationszentrum at the University of Mainz, Germany for technical support. This work has been supported by grants from the Laupitz Stiftung to MT; Wilhelm Sander Stiftung to JK and MT; and Leukemia and Lymphoma Society grant LS-7008, and NIH grants CA18029 and CA33084 to PDG.

Open Access This article is distributed under the terms of the Creative Commons Attribution Noncommercial License which permits any noncommercial use, distribution, and reproduction in any medium, provided the original author(s) and source are credited.

\section{References}

1. Molldrem J, Dermime S, Parker K, Jiang YZ, Mavroudis D, Hensel N, Fukushima P, Barrett AJ (1996) Targeted T-cell therapy for human leukemia: cytotoxic $\mathrm{T}$ lymphocytes specific for a peptide derived from proteinase 3 preferentially lyse human myeloid leukemia cells. Blood 88:2450-2457

2. Molldrem JJ, Clave E, Jiang YZ, Mavroudis D, Raptis A, Hensel N, Agarwala V, Barrett AJ (1997) Cytotoxic T lymphocytes specific for a nonpolymorphic proteinase 3 peptide preferentially inhibit chronic myeloid leukemia colony-forming units. Blood 90:2529-2534

3. Bellantuono I, Gao L, Parry S, Marley S, Dazzi F, Apperley J, Goldman JM, Stauss HJ (2002) Two distinct HLA-A0201-presented epitopes of the Wilms tumor antigen 1 can function as targets for leukemia-reactive CTL. Blood 100:3835-3837

4. Kuball J, Dossett ML, Wolfl M, Ho WY, Voss RH, Fowler C, Greenberg PD (2007) Facilitating matched pairing and expression of TCR chains introduced into human T cells. Blood 109:23312338

5. Wolfl M, Kuball J, Ho WY, Nguyen H, Manley TJ, Bleakley M, Greenberg PD (2007) Activation-induced expression of CD137 permits detection, isolation, and expansion of the full repertoire of $\mathrm{CD} 8+\mathrm{T}$ cells responding to antigen without requiring knowledge of epitope specificities. Blood 110:201-210

6. Oka Y, Tsuboi A, Taguchi T, Osaki T, Kyo T, Nakajima H, Elisseeva OA, Oji Y, Kawakami M, Ikegame K, Hosen N, 
Yoshihara S, Wu F, Fujiki F, Murakami M, Masuda T, Nishida S, Shirakata T, Nakatsuka S, Sasaki A, Udaka K, Dohy H, Aozasa K, Noguchi S, Kawase I, Sugiyama H (2004) Induction of WT1 (Wilms' tumor gene)-specific cytotoxic T lymphocytes by WT1 peptide vaccine and the resultant cancer regression. Proc Natl Acad Sci USA 101:13885-13890

7. Keilholz U, Letsch A, Busse A, Asemissen AM, Bauer S, Blau IW, Hofmann WK, Uharek L, Thiel E, Scheibenbogen C (2009) A clinical and immunologic phase 2 trial of Wilms tumor gene product 1 (WT1) peptide vaccination in patients with AML and MDS. Blood 113:6541-6548

8. Rezvani K, Yong AS, Mielke S, Savani BN, Musse L, Superata J, Jafarpour B, Boss C, Barrett AJ (2008) Leukemia-associated antigen-specific T-cell responses following combined PR1 and WT1 peptide vaccination in patients with myeloid malignancies. Blood 111:236-242

9. Hiltbold EM, Ciborowski P, Finn OJ (1998) Naturally processed class II epitope from the tumor antigen MUC1 primes human CD4 + T cells. Cancer Res 58:5066-5070

10. Domenech N, Henderson RA, Finn OJ (1995) Identification of an HLA-A11-restricted epitope from the tandem repeat domain of the epithelial tumor antigen mucin. J Immunol 155:4766-4774

11. Brossart P, Wirths S, Stuhler G, Reichardt VL, Kanz L, Brugger W (2000) Induction of cytotoxic T-lymphocyte responses in vivo after vaccinations with peptide-pulsed dendritic cells. Blood 96:3102-3108

12. Brossart P, Schneider A, Dill P, Schammann T, Grunebach F, Wirths S, Kanz L, Buhring HJ, Brugger W (2001) The epithelial tumor antigen MUC1 is expressed in hematological malignancies and is recognized by MUC1-specific cytotoxic T-lymphocytes. Cancer Res 61:6846-6850

13. Gulley JL, Arlen PM, Tsang KY, Yokokawa J, Palena C, Poole DJ, Remondo C, Cereda V, Jones JL, Pazdur MP, Higgins JP, Hodge JW, Steinberg SM, Kotz H, Dahut WL, Schlom J (2008) Pilot study of vaccination with recombinant CEA-MUC-1-TRICOM poxviral-based vaccines in patients with metastatic carcinoma. Clin Cancer Res 14:3060-3069

14. Smith JW, Walker EB, Fox BA, Haley D, Wisner KP, Doran T, Fisher B, Justice L, Wood W, Vetto J, Maecker H, Dols A, Meijer S, Hu HM, Romero P, Alvord WG, Urba WJ (2003) Adjuvant immunization of HLA-A2-positive melanoma patients with a modified gp100 peptide induces peptide-specific CD8+ T-cell responses. J Clin Oncol 21:1562-1573

15. van Driel WJ, Ressing ME, Kenter GG, Brandt RM, Krul EJ, van Rossum AB, Schuuring E, Offringa R, Bauknecht T, TammHermelink A, van Dam PA, Fleuren GJ, Kast WM, Melief CJ, Trimbos JB (1999) Vaccination with HPV16 peptides of patients with advanced cervical carcinoma: clinical evaluation of a phase I-II trial. Eur J Cancer 35:946-952

16. Rosenberg SA, Yang JC, Schwartzentruber DJ, Hwu P, Marincola FM, Topalian SL, Restifo NP, Dudley ME, Schwarz SL, Spiess PJ, Wunderlich JR, Parkhurst MR, Kawakami Y, Seipp CA, Einhorn JH, White DE (1998) Immunologic and therapeutic evaluation of a synthetic peptide vaccine for the treatment of patients with metastatic melanoma. Nat Med 4:321-327

17. Speiser DE, Lienard D, Rufer N, Rubio-Godoy V, Rimoldi D, Lejeune F, Krieg AM, Cerottini JC, Romero P (2005) Rapid and strong human $\mathrm{CD} 8+\mathrm{T}$ cell responses to vaccination with peptide, IFA, and CpG oligodeoxynucleotide 7909. J Clin Invest 115:739-746

18. Pashenkov M, Goess G, Wagner C, Hormann M, Jandl T, Moser A, Britten CM, Smolle J, Koller S, Mauch C, Tantcheva-Poor I, Grabbe S, Loquai C, Esser S, Franckson T, Schneeberger A, Haarmann C, Krieg AM, Stingl G, Wagner SN (2006) Phase II trial of a toll-like receptor 9-activating oligonucleotide in patients with metastatic melanoma. J Clin Oncol 24:5716-5724
19. Valmori D, Souleimanian NE, Tosello V, Bhardwaj N, Adams S, O’Neill D, Pavlick A, Escalon JB, Cruz CM, Angiulli A, Angiulli F, Mears G, Vogel SM, Pan L, Jungbluth AA, Hoffmann EW, Venhaus R, Ritter G, Old LJ, Ayyoub M (2007) Vaccination with NY-ESO-1 protein and $\mathrm{CpG}$ in Montanide induces integrated antibody/Th1 responses and CD8 T cells through cross-priming. Proc Natl Acad Sci USA 104:8947-8952

20. Speiser DE, Baumgaertner P, Voelter V, Devevre E, Barbey C, Rufer N, Romero P (2008) Unmodified self antigen triggers human CD8 $\mathrm{T}$ cells with stronger tumor reactivity than altered antigen. Proc Natl Acad Sci USA 105:3849-3854

21. Molenkamp BG, Sluijter BJ, van Leeuwen PA, Santegoets SJ, Meijer S, Wijnands PG, Haanen JB, van den Eertwegh AJ, Scheper RJ, de Gruijl TD (2008) Local administration of PF-3512676 CpG-B instigates tumor-specific CD8+ T-cell reactivity in melanoma patients. Clin Cancer Res 14:4532-4542

22. Huber C, Bobek N, Kuball J, Thaler S, Hoffarth S, Huber C, Theobald M, Schuler M (2005) Inhibitors of apoptosis confer resistance to tumour suppression by adoptively transplanted cytotoxic T-lymphocytes in vitro and in vivo. Cell Death Differ 12:317-325

23. Ho WY, Nguyen HN, Wolfl M, Kuball J, Greenberg PD (2006) In vitro methods for generating $\mathrm{CD} 8(+) \mathrm{T}$-cell clones for immunotherapy from the naive repertoire. J Immunol Methods 310:40-52

24. Pepperl-Klindworth S, Besold K, Frankenberg N, Farkas M, Kuball J, Theobald M, Plachter B (2006) Cytomegalovirus interleukin-10 expression in infected cells does not impair MHC class I restricted Peptide presentation on bystanding antigenpresenting cells. Viral Immunol 19:92-101

25. Alexander J, Fikes J, Hoffman S, Franke E, Sacci J, Appella E, Chisari FV, Guidotti LG, Chesnut RW, Livingston B, Sette A (1998) The optimization of helper T lymphocyte (HTL) function in vaccine development. Immunol Res 18:79-92

26. Alexander J, Sidney J, Southwood S, Ruppert J, Oseroff C, Maewal A, Snoke K, Serra HM, Kubo RT, Sette A et al (1994) Development of high potency universal DR-restricted helper epitopes by modification of high affinity DR-blocking peptides. Immunity 1:751-761

27. Cheson BD, Bennett JM, Kopecky KJ, Buchner T, Willman CL, Estey EH, Schiffer CA, Doehner H, Tallman MS, Lister TA, LoCoco F, Willemze R, Biondi A, Hiddemann W, Larson RA, Lowenberg B, Sanz MA, Head DR, Ohno R, Bloomfield CD (2003) Revised recommendations of the international working group for diagnosis, standardization of response criteria, treatment outcomes, and reporting standards for therapeutic trials in acute myeloid leukemia. J Clin Oncol 21:4642-4649

28. Blade J, Samson D, Reece D, Apperley J, Bjorkstrand B, Gahrton G, Gertz M, Giralt S, Jagannath S, Vesole D (1998) Criteria for evaluating disease response and progression in patients with multiple myeloma treated by high-dose therapy and haemopoietic stem cell transplantation. Myeloma Subcommittee of the EBMT. European Group for Blood and Marrow Transplant. Br J Haematol 102:1115-1123

29. Barber DL, Wherry EJ, Masopust D, Zhu B, Allison JP, Sharpe $\mathrm{AH}$, Freeman GJ, Ahmed R (2006) Restoring function in exhausted CD8 $\mathrm{T}$ cells during chronic viral infection. Nature 439:682-687

30. Teague RM, Sather BD, Sacks JA, Huang MZ, Dossett ML, Morimoto J, Tan X, Sutton SE, Cooke MP, Ohlen C, Greenberg PD (2006) Interleukin-15 rescues tolerant CD8+ T cells for use in adoptive immunotherapy of established tumors. Nat Med 12:335-341

31. Moseman EA, Liang X, Dawson AJ, Panoskaltsis-Mortari A, Krieg AM, Liu YJ, Blazar BR, Chen W (2004) Human plasmacytoid dendritic cells activated by $\mathrm{CpG}$ oligodeoxynucleotides 
induce the generation of $\mathrm{CD} 4+\mathrm{CD} 25+$ regulatory $\mathrm{T}$ cells. J Immunol 173:4433-4442

32. Jarnicki AG, Conroy H, Brereton C, Donnelly G, Toomey D, Walsh K, Sweeney C, Leavy O, Fletcher J, Lavelle EC, Dunne P, Mills KH (2008) Attenuating regulatory T cell induction by TLR agonists through inhibition of p38 MAPK signaling in dendritic cells enhances their efficacy as vaccine adjuvants and cancer immunotherapeutics. J Immunol 180:3797-3806

33. Gnjatic S, Altorki NK, Tang DN, Tu SM, Kundra V, Ritter G, Old LJ, Logothetis CJ, Sharma P (2009) NY-ESO-1 DNA vaccine induces $\mathrm{T}$-cell responses that are suppressed by regulatory $\mathrm{T}$ cells. Clin Cancer Res 15:2130-2139

34. Molenkamp BG, van Leeuwen PA, Meijer S, Sluijter BJ, Wijnands PG, Baars A, van den Eertwegh AJ, Scheper RJ, de Gruijl TD (2007) Intradermal CpG-B activates both plasmacytoid and myeloid dendritic cells in the sentinel lymph node of melanoma patients. Clin Cancer Res 13:2961-2969

35. Dzionek A, Inagaki Y, Okawa K, Nagafune J, Rock J, Sohma Y, Winkels G, Zysk M, Yamaguchi Y, Schmitz J (2002) Plasmacytoid dendritic cells: from specific surface markers to specific cellular functions. Hum Immunol 63:1133-1148

36. Maslak PG, Dao T, Krug LM, Chanel S, Korontsvit T, Zakhaleva V, Zhang R, Wolchok JD, Yuan J, Pinilla-Ibarz J, Berman E, Weiss M, Jurcic J, Frattini MG, Scheinberg DA (2010) Vaccination with synthetic analog peptides derived from WT1 oncoprotein induces $\mathrm{T}$-cell responses in patients with complete remission from acute myeloid leukemia. Blood 116:171-179

37. Van Tendeloo VF, Van De Velde CJ, Van Driessche A, Cools N, Anguille S, Ladell K, Gostick E, Vermeulen K, Pieters K, Nijs G, Stein B, Smits EL, Schroyens WA, Gadisseur AP, Vrelust I, Jorens PG, Goossens H, de Vries I, Price DA, Oji Y, Oka Y, Sugiyama H, Berneman ZN (2010) Induction of complete and molecular remissions in acute myeloid leukemia by Wilms' tumor 1 antigen-targeted dendritic cell vaccination. Proc Natl Acad Sci USA 107:13824-13829

38. Choi C, Witzens M, Bucur M, Feuerer M, Sommerfeldt N, Trojan A, Ho A, Schirrmacher V, Goldschmidt H, Beckhove P (2005) Enrichment of functional CD8 memory T cells specific for MUC1 in bone marrow of patients with multiple myeloma. Blood 105:2132-2134

39. Gajewski TF, Meng Y, Blank C, Brown I, Kacha A, Kline J, Harlin H (2006) Immune resistance orchestrated by the tumor microenvironment. Immunol Rev 213:131-145

40. Aichele P, Brduscha-Riem K, Zinkernagel RM, Hengartner H, Pircher H (1995) T cell priming versus T cell tolerance induced by synthetic peptides. J Exp Med 182:261-266

41. Toes RE, Blom RJ, Offringa R, Kast WM, Melief CJ (1996) Enhanced tumor outgrowth after peptide vaccination. Functional deletion of tumor-specific CTL induced by peptide vaccination can lead to the inability to reject tumors. J Immunol 156:3911-3918
42. Bonifaz L, Bonnyay D, Mahnke K, Rivera M, Nussenzweig MC, Steinman RM (2002) Efficient targeting of protein antigen to the dendritic cell receptor DEC-205 in the steady state leads to antigen presentation on major histocompatibility complex class I products and peripheral $\mathrm{CD} 8+\mathrm{T}$ cell tolerance. $\mathrm{J}$ Exp Med 196:1627-1638

43. Orleans-Lindsay JK, Barber LD, Prentice HG, Lowdell MW (2001) Acute myeloid leukaemia cells secrete a soluble factor that inhibits $\mathrm{T}$ and NK cell proliferation but not cytolytic function-implications for the adoptive immunotherapy of leukaemia. Clin Exp Immunol 126:403-411

44. Chamuleau ME, van de Loosdrecht AA, Hess CJ, Janssen JJ, Zevenbergen A, Delwel R, Valk PJ, Lowenberg B, Ossenkoppele GJ (2008) High INDO (indoleamine 2, 3-dioxygenase) mRNA level in blasts of acute myeloid leukemic patients predicts poor clinical outcome. Haematologica 93:1894-1898

45. Kedl RM, Rees WA, Hildeman DA, Schaefer B, Mitchell T, Kappler J, Marrack P (2000) T cells compete for access to antigen-bearing antigen-presenting cells. J Exp Med 192:1105-1113

46. Seder RA, Darrah PA, Roederer M (2008) T-cell quality in memory and protection: implications for vaccine design. Nat Rev Immunol 8:247-258

47. Kim D, Monie A, He L, Tsai YC, Hung CF, Wu TC (2008) Role of IL-2 secreted by PADRE-specific CD4+ T cells in enhancing E7specific CD8+ T-cell immune responses. Gene Ther 15:677-687

48. Krieg AM (2007) Development of TLR9 agonists for cancer therapy. J Clin Invest 117:1184-1194

49. Karan D, Krieg AM, Lubaroff DM (2007) Paradoxical enhancement of CD8 T cell-dependent anti-tumor protection despite reduced CD8 $\mathrm{T}$ cell responses with addition of a TLR9 agonist to a tumor vaccine. Int J Cancer 121:1520-1528

50. Nicholaou T, Ebert LM, Davis ID, McArthur GA, Jackson H, Dimopoulos N, Tan B, Maraskovsky E, Miloradovic L, Hopkins W, Pan L, Venhaus R, Hoffman EW, Chen W, Cebon J (2009) Regulatory T-cell-mediated attenuation of T-cell responses to the NY-ESO-1 ISCOMATRIX vaccine in patients with advanced malignant melanoma. Clin Cancer Res 15:2166-2173

51. Kordasti SY, Ingram W, Hayden J, Darling D, Barber L, Afzali B, Lombardi G, Wlodarski MW, Maciejewski JP, Farzaneh F, Mufti GJ (2007) CD4+ CD25high Foxp3 + regulatory T cells in myelodysplastic syndrome (MDS). Blood 110:847-850

52. Giannopoulos K, Dmoszynska A, Kowal M, Rolinski J, Gostick E, Price DA, Greiner J, Rojewski M, Stilgenbauer S, Dohner H, Schmitt M (2010) Peptide vaccination elicits leukemia-associated antigen-specific cytotoxic CD8+ T-cell responses in patients with chronic lymphocytic leukemia. Leukemia 24:798-805

53. Greiner J, Schmitt A, Giannopoulos K, Rojewski MT, Gotz M, Funk I, Ringhoffer M, Bunjes D, Hofmann S, Ritter G, Dohner H, Schmitt M (2010) High-dose RHAMM-R3 peptide vaccination for patients with acute myeloid leukemia, myelodysplastic syndrome and multiple myeloma. Haematologica 95:1191-1197 